Innlegg på inntil $\mathbf{4 0 0}$ ord lastes opp i http://mc.manuscriptcentral.com/tidsskriftet.

Redaksjonen forbeholder seg retten til å foreta redaksjonelle endringer.

Forfattere av vitenskapelige artikler har tilsvarsrett (jf. Vancouver-gruppens regler).

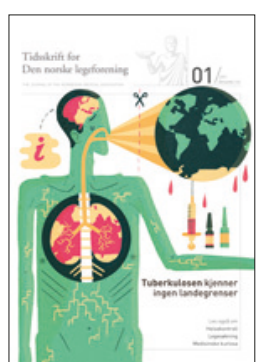

\section{Ortopeder og kommersielle interesser}

I Tidsskriftet nr. 1/2012 mener Engesæter og medarbeidere (1) at jeg i min kronikk om samrøret mellom ortopeder og industrien i USA (2) burde ha omtalt den kontinuerlige overvåking av ortopediske produkter som gjøres i regi av Nasjonalt register for leddproteser (1). Slike registerdata genererer utvilsomt nyttig kunnskap, blant annet om implantatoverlevelse og reoperasjonsårsaker. Registerets økonomiske uavhengighet gjør at man kan feste lit til materialet. Det finnes for øvrig til sammen 29 tilsvarende nasjonale eller regionale registre på verdensbasis. Det man imidlertid savner i det norske registeret, er data om pasienttilfredshet.

Siktemålet med min kronikk var imidlertid å sette søkelys på den ofte mangelfulle og selektive kliniske dokumentasjon som foreligger $f ø r$ innføring av medisinskteknisk utstyr (pre-market testing). Det finnes eksempler på ortopediske produkter som aldri skulle vært sluppet på markedet og hvor selv godt oppdaterte proteseregistre ikke påviste svikt før katastrofen var et faktum. Gjennom det norske proteseregisteret ble svikten av protesesementen Bonelock avdekket tidlig i 1990-årene, men da var produktet allerede anvendt hos 1300 pasienter (3).

Et annet eksempel er hofteproteser av typen metall-på-metall, som ble lansert for målgruppen yngre og aktive pasienter. En av disse var DePuys ASR-protese. Til tross for at den ble klassifisert som et risikoprodukt, ble den i 2005 i henhold til en forenklet prosedyre godkjent av FDA til klinisk bruk, uten forutgående klinisk uttesting. Den ble siden også tatt i bruk i EØSområdet. Gjennom bl.a. det britiske proteseregisteret ble det i 2010 påvist en betydelig hyppighet av tidlig protesevikt, og på årsmøtet for britiske hofteortopeder i mars 2011 ble det rapportert opptil $49 \%$ svikt ved denne protesetypen allerede etter seks år. Det er blitt anslått at 40000 briter i verste fall vil måtte få skiftet ut slike proteser de kommende år (4).

Fordi proteseprodusentene til stadighet gjør mindre design- og materialendringer, blir løpende kontrolltiltak omtrent som å skyte på bevegelig blink. Tilsynelatende små endringer kan gi uforutsette kliniske konsekvenser. ASR-svikten skyldtes utilstrekkelig klinisk utprøvning før godkjenning, fordi man antok at protesen var likeverdig med liknende proteser. Skandalen kunne skje på tross av godt oppdaterte proteseregistre i flere land.

Skandinaviske ortopeder har heldigvis vært tilbakeholdne med å ta i bruk metallpå-metall-proteser, hvilket kanskje er uttrykk for en sunn skepsis til nye og relativt uprøvde protesetyper. Imidlertid benytter norske ortopeder en relativt høy andel øvrige protesetyper med dårlig dokumenterte kliniske egenskaper og usikker overlevelsestid (5). Dette kan gjenspeile at heller ikke norske ortopeder er immune mot påvirkning fra kommersielle interesser.

\section{Robin Holtedahl}

Avdeling for fysikalsk medisin og rehabilitering Sykehuset Buskerud

Robin Holtedahl (f. 1948) er spesialist i fysikalsk medisin og rehabilitering og praktiserende spesialist.

Ingen oppgitte interessekonflikter.

\section{Litteratur}

1. Engesæter LB, Havelin LI, Furnes O. Uavhengige forskningsmiljøer finnes! Tidsskr Nor Legeforen 2012: 132: 12-3.

2. Holtedahl R. Ortopeder i lommen på industrien. Tidsskr Nor Legeforen 2011; 131: 2250-3.

3. Furnes 0 . Hofteproteser og sement. Tidsskr Nor Lægeforen 2004; 124: 2395.

4. Ungoed-Thomas J, Duffill G. Tumor fear over metal hip replacements. Sunday Times 18.4.2010.

5. Valg av implantater ved innsetting av primær total hofteprotese i Norge. SMM-rapport nr. 6/2002. Oslo: Senter for medisinsk metodevurdering, 2002

\section{Psykoterapiveiledning i spesialistutdanningen}

Leder i psykoterapiutvalget Bente Øvensen og leder i spesialitetskomiteen Morten S. Selle kom i Tidsskriftet nr. 1/2012 med svar (1) til et innlegg (2) i en debatt rundt den rollen kognitiv terapi, også kalt kognitiv atferdsterapi, skal ha i psykiaterutdanningen. Svaret er for en stor del en oppsum- mering av historiske fakta rundt tilblivelsen av dagens ordning. Det fremheves at det i utdanningen bør være en grunnleggende innføring i lege-pasient-forholdets dynamikk og at psykodynamisk teori best ivaretar dette behovet. Vi etterlyser en argumentasjon for dette synet.

I den kognitive terapitradisjonen vektlegges kunnskap om lege-pasient-forholdet i høy grad, og en betydelig andel av forskningen og metodeutviklingen vedrørende den terapeutiske allianse skjer innenfor kognitiv terapi. Vi har derfor problemer med å forstå hvorfor det kun er veiledere med utdanning i dynamisk terapi som kan gi veiledning i lege-pasient-forholdets dynamikk.

Her er det relevant å sammenlikne spesialistutdanningene i de skandinaviske land. Verken i Danmark eller Sverige står den psykodynamiske tradisjon i en særstilling, og kandidatene må lære kognitiv terapi. I Danmark er utdanningen i kognitiv terapi like omfattende som den i psykodyamisk terapi for spesialistkandidatene.

Psykoterapiveiledning vil ikke bare vektlegge lege-pasient-relasjonen, men også være veiledning i gjennomføring av behandling. Utdanningskandidatene i psykiatri må behandle pasienter etter en teoretisk modell, dermed blir psykoterapiveiledning også en opplæring i en psykodynamisk psykoterapi. Hva er det vitenskapelige grunnlaget for å hevde at denne modellen skal velges fremfor kognitiv terapi?

Hovedpoenget i Horns kommentar (2) er at en spesialistutdanning i psykiatri som ikke inneholder utdanning og praktisk erfaring med kognitiv terapi ikke er faglig optimal. Vi mener at kognitiv terapi skal være en obligatorisk del av spesialistutdanningen i psykiatri. Kognitiv terapi er en godt dokumentert og etterspurt behandlingsform som fremheves i norske og utenlandske terapianbefalinger. Våre pasienter og myndighetene forventer at legespesialister kjenner denne tilnærmingen.

I siste avsnitt skriver Øvensen \& Selle om behovet for evaluering av dagens ordning. Vi ønsker velkommen en evaluering der representanter fra de ulike sentrale anerkjente terapitilnærminger kan sette seg sammen og drøfte den fremtidige utviklingen av faget vårt.

\section{Kjetil Horn}

Egil Martinsen

Bjørn Ravneberg

Tone Madland Skeie

Moss/Oslo/Stavanger 
Kjetil Horn (f. 1966) er overlege i TIPS-teamet ved Sykehuset Østfold HF, Divisjon psykiatri. Han er veileder i kognitiv terapi.

Ingen oppgitte interessekonflikter.

Egil W. Martinsen (1950) er professor ved Det medisinske fakultet, Universitetet i Oslo. Han er overlege, leder av Avdeling for forskning og utvikling, Klinikk psykisk helse og avhengighet, Oslo universitetssykehus, og har vært leder av Norsk forening for kognitiv terapi.

Ingen oppgitte interessekonflikter.

Bjørn Ravneberg (f. 1960) er privatpraktiserende spesialist i psykiatri i Oslo. Han er godkjent psykoterapiveileder i kognitiv terapi, medlem av Psykoterapiutvalget og av styret i Norsk forening for kognitiv terapi.

Ingen oppgitte interessekonflikter.

Tone Madland Skeie (f. 1959) er overlege/psykiater ved Enhet for spiseforstyrrelser, Stavanger universitetssjukehus. Hun er godkjent psykoterapiveileder i gruppepsykoterapi og kognitiv terapi og ansatt som psykoterapiveileder i kognitiv terapi (10\%-stilling) ved Psykiatrisk divisjon. Skeie er styremedlem i Norsk forening for kognitiv terapi.

Ingen oppgitte interessekonflikter.

\section{Litteratur}

1. Øvensen B, Selle MS. Psykoterapiveiledning i spesialistutdanningen. Tidsskr Nor Legeforen 2012; 132: 13.

2. Horn K. Psykodynamisk terapi og kognitiv terapi bør likestilles. Tidsskr Nor Legeforen 2012; 132 1989-90.

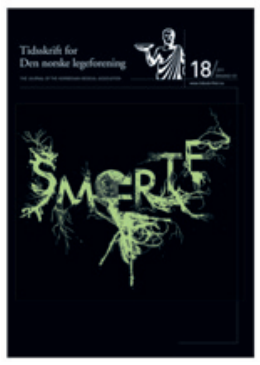

\section{Dopinganalyse på trygg grunn}

I en kommentar i Tidsskriftet nr. 18/2011, med referanse til den såkalte Tysse-saken, deler Waaler og medarbeidere noen refleksjoner om dopingtesting generelt og om testingen i den spesifikke saken spesielt (1). Kappgjenger Erik Tysse ble dømt for brudd på bestemmelsene i World Anti-Doping Code og NIFs lov, fordi CERA (Continuous Erythropoietin Receptor Activator), et erytropoietinpreparat (EPO-preparat) ble identifisert i urinprøven hans. Det bør nevnes at forfatterne kommenterer saken etter avgjørelsen i NIFs domsutvalg. I ettertid har det vært en ankesak for Court of Arbitration for
Sport (CAS) i Lausanne, der dommen fra

NIFs domsutvalg ble opprettholdt (2).

Når det gjelder den generelle beskrivelsen av en analysemetodes karakteristika som repeterbarhet, sensitivitet og spesifisitet, eller forklaringen på tilfeldige og systematiske feil samt prediksjonskraften, har ikke vi noe å tilføye. Dette fordi forfatterne forklarer disse begrepene, forståelig nok anvendt på medisinske problemer, svært godt. Problemet oppstår når man trekker uriktige konklusjoner om validiteten til en analytisk metode ved kun å støtte seg til protokollen til Domsutvalgets avgjørelse og avkreftede uttalelser fra den muntlige høringen.

Metodens validitet er ikke dokumentert gjennom en A- og B-analyse av en utøvers urinprøve, men er basert på en akkrediteringsprosedyre i hvert enkelt WADA-akkreditert laboratorium i henhold til internasjonale laboratoriestandarder. Dette kommer også til uttrykk i vurderingen av et kompetent og uavhengig dommerpanel i Court of Arbitration for Sport under punkt 8.15 (2). Vi er på trygg analytisk-toksikologisk og rettstoksikologisk grunn når det gjelder adekvat validering av denne metoden og alle andre analysemetoder i dopinganalysen.

Forutsetningen for at et WADA-akkreditert laboratorium kan anvende en analytisk metode, er at den er godkjent av WADA og akkreditert $\mathrm{i}$ henhold til en internasjonal ISO/IEC-standard 17025: 2005. I tillegg utgir WADA et spesifikt teknisk dokument som skrives av fagfolk som har særlig erfaring med den gjeldende metoden. Dokumentet er resultatet av en inngående konsultasjonsprosess. De kriterier og krav som stilles for påvisning av rekombinant EPO og analoger er beskrevet der, sammen med relevante referanser (3).

Spesifisitet (selektivitet) er den viktigste valideringsparameteren for ikke å få falskt positive resultater. I perioden 2000-07, hvor CERA ennå ikke var på markedet, ble det ved WADA-laboratoriene i Roma, Paris og Oslo analysert mer enn 8000 urinprøver med analysemetoden for EPO. Ingen av disse prøvene hadde en isoelektrisk EPOprofil som liknet en positiv prøve for CERA, og dette demonstrerer graden av spesifisitet for den valgte metoden.

Det er vår konklusjon at en korrekt analytisk og juridisk prosess er blitt fulgt i Tysse-saken før endelig dom ble avsagt av en uavhengig domstol.

\section{Peter Hemmersbach}

Norges laboratorium for dopinganalyse

Oslo universitetssykehus

Farmasøytisk institutt

Universitetet i Oslo

\section{Mads Drange}

Stiftelsen Antidoping Norge

\section{Olivier Rabin}

World Anti-Doping Agency

Montreal, Canada

\section{Francesco Botrè}

Laboratorio Antidoping FMSI

Roma

\section{Yvette Dehnes}

Norges laboratorium for dopinganalyse Oslo universitetssykehus

Peter Hemmersbach (f. 1950) er Diplom-Chemiker, dr.rer.nat. og laboratorieleder for Norges laboratorium for dopinganalyse ved Oslo universitetssykehus. Han har en prof Il-stilling for legemiddel- og dopinganalyse ved Farmasøytisk institutt, Universitetet i Oslo. Ingen oppgitte interessekonflikter.

Mads Drange (f. 1981) har en mastergrad i muskelfysiologi fra Norges idrettshøgskole. Han er avdelingsleder for avdeling for toppidrett \& utvikling i Antidoping Norge, som drifter dopingkontrollprogrammet i norsk idrett. Ingen oppgitte interessekonflikter.

Olivier Rabin (b. 1965) holds a PhD in pharmacology and toxicology and a degree in biomedical engineering. Since 2002, he occupies the position of Science Director of the World AntiDoping Agency i Montreal.

Ingen oppgitte interessekonflikter.

Francesco Botrè (b. 1962) has academic degrees in chemistry and in pharmacy, postdoctorate specialization in experimental pharmacology. He is director of the Italian WADA-accredited anti-doping laboratory, professor of advanced methods for the analysis of drugs and metabolites, and of analysis of biopharmaceuticals at the School of Pharmaceutical Chemistry and at the School of Pharmaceutical Biotechnology of the «Sapienza» University of Rome.

Ingen oppgitte interessekonflikter.

Yvette Dehnes (f. 1969) er cand.scient. i analytisk kjemi fra Universitetet i Oslo. Hun er faglig ansvarlig for proteinanalyser ved Norges laboratorium for dopinganalyse, Oslo universitetssykehus.

Ingen oppgitte interessekonflikter.

Litteratur

1. Waaler H, Siem H, Aalen O. Kan vi stole på dopingtestingen? Tidsskr Nor Legeforen 2011; 131: 1760-1.

2. Tribunal arbitral du sport/Court of Arbitration for Sport. CAS 2011/A/2353 Erik Tysse. www.tascas.org (7.10.2011)

3. TD2009EPO. Harmonization of the method for the identification of recombinant erythropoietins li.e. epoetins) and analogues (e.g. darbepoietin and methoxypolyethylene glycol-epoetin betal. www.wada-ama.org/Documents/World AntiDoping_Program/WADP-IS-Laboratories/ Technical_Documents/ WADA_TD2009EPO_Harmonization of Method Identificiation Recombinant Erythropoietins Analogues EN..$p d f(7.10 .201 \overline{1})$. på www.tidsskriftet.no 